\title{
THE WOLFENDEN REPORT
}

The Report of the Committee on Homosexual Offences and Prostitution* (to give it its full name) is an enlightened and realistic document and reflects the greatest credit on the civilized and humane outlook of the members of the Committee. The Street Offences Committee 1927, under the Chairmanship of Mr. Hugh Macmillan, K.C., had stated:

"As a general proposition it will be universally accepted that the law is not concerned with private morals or with ethical sanctions. On the other hand, the law is plainly concerned with the outward conduct of citizens in so far as the conduct injuriously affects the rights of other citizens. Certain forms of conduct it has always been thought right to bring within the scope of the criminal law on account of the injury which they occasion to the public in general".

The Wolfenden Committee accepted this statement as, in general, representing their own approach.

The Committee's analysis of homosexuality, homosexual behaviour, and homosexual offences has led to recommendations that are unacceptable to many but, on prostitution, the Committee's views and recommendations will receive wide endorsement. The main object of the Committee is to remove from the streets the affront to public decency presented by the presence of prostitutes looking for customers. The Committee therefore recommends a higher initial fine and steeply rising penalties for subsequent offences. They note with approval the practice followed in Edinburgh and Glasgow whereby

\footnotetext{
* Cmnd. 247. H.M.S.O., London. 5s.
}

women starting on a life of prostitution are first cautioned by a police officer in the streets and then if necessary subsequently brought to court for a further caution. Persistence in soliciting in the street after these procedures would then result in a woman's being brought to court and charged. The streets would become less desirable hunting grounds for prostitutes because of the heavy and increasing penalties, but, unless life as a prostitute is to be made impossible by law (which the Committee rejects), prostitutes must be permitted to operate in private, always provided that no breach of the peace and no offence to neighbours are occasioned.

The Committee rightly sets its face against any form of licensing prostitutes or brothels. There is a good case for regular medical examination of prostitutes in the interests of their own health which is at a very considerable occupational risk. Those that attend the V.D. clinic should be encouraged to report regularly for tests and treatment. This will provide no guarantee that their clients will be protected but will help to reduce the "reservoir" of gonococcal infection in the most promiscuous part of the female population.

We think that, in respect of prostitution, the Wolfenden Report is to be approved as a very great advance in the handling of the problems which constituted its terms of reference and, whatever the legislative fate of its recommendations, we are sure that the Report will do much to bring about those gradual alterations of public opinion which are so often an indispensable progenitor of alterations in the law. 